\title{
Characterization of genetic coefficients of durum wheat (Triticum turgidum L. ssp. durum) 'Llareta-INIA' and 'Corcolén-INIA'
}

\author{
Marco Garrido $^{1 *}$, Luis Román ${ }^{2}$, Paola Silva ${ }^{1}$, Giorgio Castellaro ${ }^{1}$, Víctor García de Cortázar ${ }^{1}$, \\ and Edmundo Acevedo ${ }^{1}$
}

\begin{abstract}
The genetic coefficients, representative of a crop, are necessary to use growth models; in many cases the range of the species is known, but there are no specific values for varieties. Durum wheat (Triticum turgidum L. ssp. durum) 'LlaretaINIA' and 'Corcolén-INIA' were sown under irrigation in the experiment station Antumapu of the Universidad de Chile on 29 June 2007, 19 May 2009, and 15 June 2010 in order to determinate four genetic coefficients: developmental thermal time, phyllochron (PHLN), extinction coefficient $(k)$, and radiation use efficiency (RUE), and to evaluate the performance of these coefficients. Thermal times to anthesis and from anthesis to physiological maturity were 652 and $541{ }^{\circ} \mathrm{C} d$, respectively. Two PHLN values were found, $46.6^{\circ} \mathrm{C} \mathrm{d}$ leaf ${ }^{-1}$ from emergence to fifth leaf and $102.9^{\circ} \mathrm{C} \mathrm{d}$ leaf ${ }^{-1}$ from fifth to eighth leaf. In both cases neither variety nor sowing date was significant. The value of $k$ did not vary among sowing dates for 'Llareta-INIA' and was not significantly different from that of 'Corcolén-INIA' for normal planting date, due to which a single fit for the two varieties was adjusted, obtaining a value of 0.46 . However, 'Corcolén-INIA' had a lower value of $k$ for later sowing dates. RUE did not vary between varieties or sowing dates; its estimated value was $2.83 \mathrm{~g} \mathrm{MJ}^{-1}$. The evaluation of the coefficients obtained showed coherent results, thus they can be used in model simulations.
\end{abstract}

Key words: Simulation, thermal time, radiation use efficiency, extinction coefficient.

\section{INTRODUCTION}

Durum wheat (Triticum turgidum L. ssp. durum), used in the production of pasta, is produced in the central zone of Chile with a Mediterranean climate; $90 \%$ of the production is irrigated, and this species supplies $50 \%$ of the national demand (Silva et al., 2007). Its production has been progressively displaced towards the south of the country due to the use of the soil for more profitable crops. Today there are new environments cultivated with durum wheat, as far south as Biobío Region. Thus, for predictive purposes, it is relevant to have tools, such as simulation models to facilitate decision-making for agronomic variables, including sowing date and variety, especially in a Mediterranean-type environment (Turner, 2004), considered to be hotspots for climatic change (Diffenbaugh et al., 2007). There have been a number of successful experiences in the use of models for wheat to describe and explain the response of varieties to different environments and agricultural managements. Examples include sowing date in temperate conditions with the CERES-Wheat model in bread wheat (Kaur et al.,

${ }^{1}$ Universidad de Chile, Facultad de Ciencias Agronómicas, Casilla 1004, Santiago, Chile. .Corresponding author(marcogr@ug.uchile.cl). ${ }^{2}$ Instituto Investigaciones Agropecuarias INIA, Magallanes 1865, Arica, Chile.

Received: 6 November 2012.

Accepted: 29 April 2013.

doi:10.4067/S0718-58392013000200002.
2007), different water and $\mathrm{N}$ regimes in Mediterranean environments with CropSyst for durum wheat (Pala et al., 1996), optimization of sowing date in Mediterranean environments with APSIM for durum wheat (Bassu et al., 2009), and different irrigation regimes in Mediterranean environments with CERES-Wheat in durum wheat (Rinaldi, 2004).

A successful simulation requires an adequate description of leaf area index (LAI), extinction coefficient and radiation use efficiency (O'Connell et al., 2004). The simulation of development time is also essential, since it defines the time during which growth occurs (Stapper and Lilley, 2001). One of the simplest independent variables to quantify the development of crops is the thermal time, used in the simulation of phenological and morphological development, related to the phyllochron, defined as the time between the appearances of two successive leaves. In modeling, the parameters mentioned above are known as genetic coefficients, which are characteristics of the genotype and have little interaction with the environment (Sinclair and Muchow, 1999; Reynolds et al., 2000; Kemanian et al., 2004). The number and type of genetic coefficients necessary for a simulation is associated to the complexity of the model. Various genetic coefficients have been experimentally determined for wheat (Del Pozo, 1988; Takahashi and Nakaseko, 1990; Gregory et al., 1992), however, in durum wheat information is very limited, and does not exist for 'Llareta-INIA' and 'Corcolén-INIA'. 
The objectives of this study were (i) to determine the value of the main genetic coefficients associated with the development and growth of the most-grown Chilean varieties of durum wheat and confirm their stability under changes in environmental conditions, and (ii) to evaluate the performance of the genetic coefficients in a simple wheat model for environmental conditions different from the study.

\section{MATERIALS AND METHODS}

\section{Site description}

The experiment was performed in the Antumapu experiment station of the Facultad de Ciencias Agronómicas of the Universidad de Chile, Región Metropolitana (3340' S, $70^{\circ} 38^{\prime} \mathrm{W}, 605 \mathrm{~m}$ a.s.1.), Chile. Antumapu is within a zone of temperate mesothermal stenothermal semi-arid Mediterranean climate. The yearly temperature varies from a mean monthly maximum of $29^{\circ} \mathrm{C}$ in January to a mean minimum of $2.8^{\circ} \mathrm{C}$ in July. It accumulates 1528 degreedays (base $10^{\circ} \mathrm{C}$ ) per year, 1232 cold hours annually and mean annual rainfall of $369.5 \mathrm{~mm}$ (INIA, 1989). The soil belongs to the Santiago Series (CIREN, 1996), of alluvial origin, medium $(60 \mathrm{~cm})$ depth, flat without micro relief in the position of a large alluvial cone, with fine sandy loam texture at the surface (coarse loamy over sandy, skeletal, mixed, thermic Entic Haploxeroll).

\section{Field experiment description}

We sowed two varieties of durum wheat (Triticum turgidum L. ssp. durum), 'Llareta-INIA' and 'CorcolénINIA', on three dates: 29 June 2007, 19 May and 15 June 2010. The experimental design was randomized complete blocks with four replicates. In the first season the experimental unit was a plot of $57.8 \mathrm{~m}^{2}$ and in the second of $39 \mathrm{~m}^{2}$. In each case sowing was mechanical; the particular characteristics of each trial are given in Table 1.

Nitrogen was applied as urea, $1 / 3$ at sowing and 2/3 at the first node stage. Phosphorous and $\mathrm{K}$ were applied at sowing. Pests, diseases, and weeds were controlled to assure optimum growth. Experiments were watered by sprinkling, using an irrigation threshold of $50 \%$ available humidity in the soil profile $(60 \mathrm{~cm})$. In 20 June 2007

Table 1. Sowing date, variety, planting rate, distance between rows, plant density and doses of nitrogen, phosphorous, and potassium (N-P-K) applied in each experiment.

\begin{tabular}{llcccc}
\hline $\begin{array}{l}\text { Sowing } \\
\text { date }\end{array}$ & \multicolumn{1}{c}{ Variety } & $\begin{array}{c}\text { Planting } \\
\text { rate }\end{array}$ & $\begin{array}{c}\text { Distance } \\
\text { between } \\
\text { rows }\end{array}$ & $\begin{array}{c}\text { Plant } \\
\text { density }\end{array}$ & N-P-K \\
\hline & & $\mathrm{kg} \mathrm{ha}^{-1}$ & $\mathrm{~m}$ & plants m$^{-2}$ & $\mathrm{~kg} \mathrm{ha}^{-1}$ \\
$19-05-10$ & Llareta-INIA & 150 & 0.20 & $249 \mathrm{abc}$ & $160-120-0$ \\
$19-05-10$ & Corcolén-INIA & 150 & 0.20 & $241 \mathrm{abc}$ & $160-120-0$ \\
$29-06-07$ & Llareta-INIA & 220 & 0.18 & $258 \mathrm{ab}$ & $210-120-60$ \\
$29-06-07$ & Corcolén-INIA & 220 & 0.18 & $269 \mathrm{a}$ & $210-120-60$ \\
$15-07-10$ & Llareta-INIA & 150 & 0.20 & $237 \mathrm{bc}$ & $160-120-0$ \\
$15-07-10$ & Corcolén-INIA & 150 & 0.20 & $226 \mathrm{c}$ & $160-120-0$ \\
\hline
\end{tabular}

Values in columns followed by the same letter are not significantly different, according to Duncan's test $(\mathrm{p}>0.05)$. planting there were problems with the irrigation system just before anthesis and irrigation was deficient. Soil water content was monitored periodically using frequency domain reflectometry(Diviner 2000 device, Sentek Sensor Technologies, Stepney, Australia).

\section{Crop measurements and calculations}

The crop was observed twice weekly to determine emergence, anthesis, and physiological maturity based on Zadoks scale (Zadoks et al., 1974). Plant density was measured by counting the number of plants per meter with four observations per experimental unit between the stages of first and second fully expanded leaves.

From emergence to the seventh leaf once every $2 \mathrm{wk}$, and afterwards once a week, the fraction of photosynthetically active radiation intercepted by the crop ( $f$ IPAR) was measured with a linear ceptometer (SunScan Canopy Analysis System type SS1, Delta-T Devices, Cambridge, UK). Measurements were made in completely sunny or completely cloudy days at three moments; $2 \mathrm{~h}$ before solar zenith, at solar zenith, and $2 \mathrm{~h}$ after zenith. On the same day in which fIPAR was measured, we sampled $50 \mathrm{~cm}$ rows from each experimental unit and a sub-sample of five randomly chosen plants was collected. The main stem leaf number (MSLN) and the total green leaf area of each plant was measured using the method of Sandrini et al. (2007). The LAI $\left(\mathrm{m}^{2} \mathrm{~m}^{-2}\right)$ was calculated as the product of the plant leaf area and the number of plants per $\mathrm{m}^{2}$. Finally, the entire sample was oven dried at $70{ }^{\circ} \mathrm{C}$ to constant weight to determine dry matter per area.

The De Candolle (1855) function, weighted by a betatype function of response to the temperature (Equation [1]), was used to calculate the thermal time (TT):

$$
T T_{i}=\Sigma_{t_{i}}^{t_{f}}\left(T_{i}-T_{b}\right) f(T)_{i} \quad \text { ifTT } i<0 \text { then } T T_{i}=0
$$

To calculate temperature response function (Equation [2]) it is necessary to know cardinal temperatures for durum wheat development. According to Xue et al. (2004) the base temperature $\left(\mathrm{T}_{\mathrm{b}}\right)$ is $0{ }^{\circ} \mathrm{C}$, optimum development temperature $\left(\mathrm{T}_{\mathrm{opt}}\right)$ is $22{ }^{\circ} \mathrm{C}$, and maximum development temperature $\left(\mathrm{T}_{\max }\right)$ is $35^{\circ} \mathrm{C}$ :

$$
f(T)_{i}=\frac{2\left(T_{i}-T_{b}\right)^{\alpha} 2\left(T_{o p t}-T_{b}\right)^{\alpha}-2\left(T_{i}-T_{m i n}\right)^{2 \alpha}}{\left(T_{o p t}-T_{\min }\right)^{2 \alpha}}
$$

where $\mathrm{Ti}$ is the mean daily temperature on day $i$. When cardinal temperatures are known, as in this case, $\alpha$ may be calculated (Equation [3]).

$$
\alpha=\frac{0.69}{\operatorname{Ln} \frac{\left(T_{\max }-T_{\min }\right)}{\left(T_{\text {opt }}-T_{\min }\right)}}
$$

The phyllochron (PHLN; ${ }^{\circ} \mathrm{C} \mathrm{d} \mathrm{leaf}{ }^{-1}$ ) was estimated as the slope of the linear regression of TT on the number of leaves on the main axis.

The increase of LAI was estimated by a non-linear regression of LAI on TT, using the function: 


$$
L A L i=\frac{a}{1+\mathrm{e}^{(-b T T i-c)}}-\frac{a}{1+\mathrm{e}^{(-d T T i-f)}}
$$

where LAIi is LAI at time $i$, TTi is the thermal time at time $i, a$ is the maximum theoretical LAI of the crop (LAImax), and $b, c, d$ and $f$ are regression parameters. Monsi and Saeki (1953) used an adaptation of the law of Beer-Bougher (Rosenberg et al., 1983) to describe the attenuation of the light by the crop canopy, which was used to estimate the extinction coefficient $(k)$ of PAR by a non-linear regression of $f I P A R$ on LAI.

$$
f I P A R_{t}=1-e^{-k L A I_{t}}
$$

The radiation use efficiency (RUE; $\mathrm{g} \mathrm{MJ}^{-1}$ ) was estimated as the slope of the linear regression of accumulated aboveground biomass and accumulated PAR ( $\Sigma$ IPAR) by the crop between emergence and physiological maturity.

\section{Genetic coefficients validation}

The phenological thermal time was validated using observations on phenology obtained by Olivieri (2009) for 'Llareta-INIA' at two localities (Table 2), and yield data provided by Instituto Investigaciones Agropecuarias INIA for 'Llareta-INIA'. The meteorological data of temperature in the 2008-2009 season for Cauquenes ( $\left.35^{\circ} 55^{\prime} \mathrm{S}, 72^{\circ} 19^{\prime} \mathrm{W}\right)$, Maule Region, and Yungay (37 $07^{\prime}$ S, 72 $00^{\circ}$ W), Biobío Region, were obtained from meteorological stations located near the site of study.

The genetic coefficients relative to growth were evaluated by performing a simulation with a simple model which integrates Equation [4] for the generation of LAI as a function of thermal time and Equation [5] to estimate the amount of radiation intercepted by the crop as a function of LAI. Finally, estimated amount of IPAR was weighted by the radiation use efficiency obtained in this study, resulting in the daily production of dry material. To estimate yield we assumed that after anthesis all dry matter is distributed to the grain. The meteorological data of temperature and radiation in the 2009-2010 season for Santiago, Región Metropolitana (3334' S, 70³7' W), and Chillán ( $36^{\circ} 32^{\prime}$ S, $71^{\circ} 54^{\prime} \mathrm{W}$ ) were obtained from the meteorological stations located near the site of study.

\section{Statistical analysis}

ANOVA was performed with the InfoStat program. When significant differences among treatment means were

Table 2. Days from sowing to anthesis (S-A) and from sowing to physiological maturity (S-FM) for 'Llareta-INIA' on three sowing dates in two localities.

\begin{tabular}{lccc}
\hline Locality & Sowing date & S-A & S-FM \\
\hline Cauquenes & $31-05-2008$ & 142 & 162 \\
Cauquenes & $13-06-2008$ & 133 & 154 \\
Cauquenes & $02-07-2008$ & 118 & 138 \\
Yungay & $24-07-2008$ & 100 & 141 \\
Yungay & $19-08-2008$ & 80 & 123 \\
Yungay & $25-09-2008$ & 61 & 91 \\
\hline
\end{tabular}

found, these were tested with Duncan's test ( $\mathrm{p} \leq 0.05)$. Estimation of regression lines used the least squares method (Steel and Torrie, 1985). The regression functions obtained for both varieties and different sowing dates were submitted to a parallelism test (Cumsille, 1995) based in a two-tailed hypothesis of the Student $t$ type. With functions which could not be linearized the regression was estimated using the algorithm of Levenberg-Marquardt (Marquardt, 1963); the coefficients were compared using their $95 \%$ confidence intervals.

The performance of the model was evaluated using root mean squared error (RMSE), calculated as:

$$
R M S E=\sqrt{\frac{1}{N} \sum_{i=1}^{N}(O i-S i)^{2}}
$$

where $\mathrm{Si}$ and $\mathrm{O} i$ are the simulated and observed (measured) values as samples taken along the season, or at the end of the season, $N$ is the number of observations.

\section{RESULTS AND DISCUSSION}

\section{Growing environment}

The year 2007 had more benign minimum and maximum temperatures than 2010, also precipitation was more concentrated and the incident radiation was greater.

Table 3 shows environmental conditions for 'LlaretaINIA' and 'Corcolén-INIA' due to various sowing dates in 2007 and 2010. The later sowing date has the greater temperature and incident radiation and the lower the rainfall. The crops did not experience long periods of mean temperatures above $22{ }^{\circ} \mathrm{C}$; they generally stayed within the optimum range (Skylas et al., 2002), thus it is not expected that the crops experience important hightemperature stress.

\section{Crop phenology}

There was a significant decrease in the number of days to anthesis and physiological maturity for 'Llareta-INIA' and 'Corcolén-INIA' as sowing date was delayed (Table 4). The negative association between temperature and length of phenological phases has been widely discussed in the literature (Del Pozo, 1988; Confalone et al., 2010). Vernalization and sensitivity to photoperiod also affect phenology. However the evaluated spring wheat varieties are described as insensitive to vernalizing temperatures and photoperiod.

Bassu et al. (2009) calibrated the APSIM model (McCown et al., 1996) measuring thermal time from ear emergence to physiological maturity of three varieties of durum wheat (Simeto, Colosseo, and Creso), obtaining a mean value of $700{ }^{\circ} \mathrm{C} \mathrm{d}$, slightly greater than those measured in this study, given that the 119 mean day to ear emergence period $(\mathrm{CV}=14 \%)$ corresponded to 555 ${ }^{\circ} \mathrm{C} \mathrm{d}(\mathrm{CV}=6 \%)$. In this study the thermal time from ear emergence to physiological maturity was $638^{\circ} \mathrm{C} \mathrm{d}$ (data not shown). Jamieson et al. (1998) indicated that the 
Table 3. Monthly means of meteorological variables in the years 2007 and 2010 , and by growth season: maximum temperature ( $T_{\text {max }}$; minimum temperature $\left(\mathrm{T}_{\mathrm{min}}\right)$; monthly precipitation $(\mathrm{MP})$; global daily solar radiation (GSR) and mean duration of the crop cycle (DEM).

\begin{tabular}{|c|c|c|c|c|c|c|c|c|}
\hline \multirow[b]{2}{*}{ Month } & \multicolumn{4}{|c|}{2010} & \multicolumn{4}{|c|}{2007} \\
\hline & $\mathrm{T}_{\max }$ & $\mathrm{T}_{\min }$ & MP & GSR & $\mathrm{T}_{\max }$ & $\mathrm{T}_{\min }$ & MP & GSR \\
\hline & ${ }^{\circ} \mathrm{C}$ & ${ }^{\circ} \mathrm{C}$ & $\mathrm{mm}$ & $\mathrm{MJ} \mathrm{m}^{-2} \mathrm{~d}^{-1}$ & ${ }^{\circ} \mathrm{C}$ & ${ }^{\circ} \mathrm{C}$ & $\mathrm{mm}$ & $\mathrm{MJ} \mathrm{m}^{-2} \mathrm{~d}^{-1}$ \\
\hline June & 15.7 & 2.0 & 75 & 6.9 & - & - & - & - \\
\hline July & 13.8 & -0.3 & 26 & 8.0 & 13.5 & 1.5 & 15 & 7.9 \\
\hline August & 16.6 & 2.4 & 8 & 10.1 & 14.3 & 0.7 & 34 & 11.3 \\
\hline September & 20.2 & 3.9 & 23 & 15.3 & 17.8 & 3.7 & 2 & 15.5 \\
\hline October & 22.6 & 5.8 & 10 & 18.6 & 22.0 & 6.8 & 1 & 20.7 \\
\hline November & 26.4 & 8.7 & 34 & 23.5 & 25.7 & 8.7 & 0 & 25.5 \\
\hline December & 24.9 & 6.4 & 0 & 26.6 & 27.3 & 10.2 & 0 & 27.7 \\
\hline
\end{tabular}

\begin{tabular}{lccccc}
\hline Sowing date & $\mathrm{DEM}$ & $\mathrm{T}_{\max }$ & $\mathrm{T}_{\min }$ & $\mathrm{GSR}$ & $\mathrm{MP}$ \\
\hline & $\mathrm{d}$ & ${ }^{\circ} \mathrm{C}$ & ${ }^{\circ} \mathrm{C}$ & $\mathrm{MJ} \mathrm{m}^{-2} \mathrm{~d}^{-1}$ & $\mathrm{~mm}$ \\
$19-05-2010$ & 136 & 19.1 & 3.7 & 13.6 & 176 \\
$29-06-2007$ & 102 & 20.5 & 5.4 & 16.1 & 53 \\
$15-07-2010$ & 90 & 22.0 & 5.5 & 18.1 & 69 \\
\hline
\end{tabular}

Table 4. Days from emergence to anthesis (DA), and from anthesis to physiological maturity (DA-PM) and associated thermal times (TT and $\mathrm{TT}_{\mathrm{m}}$, respectively) for each variety and sowing date.

\begin{tabular}{lccccc}
\hline Variety & Sowing date & DA & DA-PM & TT $_{\mathrm{a}}$ & TT $_{\mathrm{m}}$ \\
\hline & & days & days & ${ }^{\circ} \mathrm{C} \mathrm{d}$ & ${ }^{\circ} \mathrm{C} \mathrm{d}$ \\
Llareta-INIA & $19-05-10$ & $137 \mathrm{a}$ & $46 \mathrm{a}$ & $640 \mathrm{a}$ & $580 \mathrm{a}$ \\
Llareta-INIA & $29-06-07$ & $103 \mathrm{~b}$ & $36 \mathrm{~b}$ & $660 \mathrm{a}$ & $503 \mathrm{ab}$ \\
Llareta-INIA & $15-07-10$ & $91 \mathrm{c}$ & $40 \mathrm{bc}$ & $682 \mathrm{a}$ & $481 \mathrm{ab}$ \\
Corcolén-INIA & $19-05-10$ & $135 \mathrm{a}$ & $46 \mathrm{a}$ & $627 \mathrm{a}$ & $566 \mathrm{a}$ \\
Corcolén-INIA & $29-06-07$ & $102 \mathrm{~b}$ & $35 \mathrm{~b}$ & $647 \mathrm{a}$ & $568 \mathrm{a}$ \\
Corcolén-INIA & $15-07-10$ & $89 \mathrm{c}$ & $39 \mathrm{ab}$ & $658 \mathrm{a}$ & $546 \mathrm{a}$ \\
\hline & Mean & 110 & 40.3 & 652 & 540.7 \\
& $\mathrm{SD}$ & 21 & 4.8 & 19 & 39.9 \\
& $\mathrm{CV}, \%$ & 19 & 11.8 & 3 & 7.4 \\
\hline
\end{tabular}

SD: standard deviation; $\mathrm{CV}$ : coefficient of variation.

Values in columns followed by the same letter are not significantly different according to Duncan's test ( $\mathrm{p}>0.05)$.

interval of thermal time from the end of the expansion of the flag leaf and anthesis is substantially more stable than the thermal time from emergence to anthesis. This phenomenon has also been observed in quinoa (Ruiz and Bertero, 2008). In this study, thermal time from emergence to anthesis remained relatively stable between sowing dates and varieties. As mentioned above, for the calculation of phenological thermal times we used the cardinal temperatures proposed by Xue et al. (2004). When different temperatures were used, thermal time between each period tended to diverge.

\section{Leaf development and growth LAI}

The PHLN was estimated as the slope of the linear functions between thermal time and the main stem leaf number. Table 5 shows that there were no significant differences among varieties and sowing dates for PHLN (slope). A change in slope was observed from fifth to eighth leaf $\left(\mathrm{PHLN}_{\mathrm{b}}\right)$, thus a linear function was adjusted for each case (Figure 1).

The increase of the PHLN after the fifth leaf may be due to the fact that the embryo of wheat has 3-4 leaves differentiated, thus their development may be more rapid than that of the following leaves, as well as to the fact the

Table 5. Phyllochron from the first to fifth leaf $\left(\mathbf{P H L N}_{\mathrm{a}}\right)$ and from the fifth to eighth leaf $\left(\right.$ PHLN $\left._{\mathrm{b}}\right)$ for each cultivar and sowing date.

\begin{tabular}{llcc}
\hline Cultivar & Sowing date & PHNL $_{\mathrm{a}}$ & PHNL $_{\mathrm{b}}$ \\
\hline & & ${ }^{\circ} \mathrm{C} \mathrm{d} \mathrm{leaf}^{-1}$ & ${ }^{\circ} \mathrm{C} \mathrm{d} \mathrm{leaf}^{-1}$ \\
Llareta-INIA & $19-05-10$ & $43.5 \mathrm{a}$ & $114.8 \mathrm{a}$ \\
Llareta-INIA & $29-06-07$ & $43.7 \mathrm{a}$ & $139.9 \mathrm{a}$ \\
Llareta-INIA & $15-07-10$ & $55.8 \mathrm{a}$ & $83.6 \mathrm{a}$ \\
Corcolén-INIA & $19-05-10$ & $43.6 \mathrm{a}$ & $108.3 \mathrm{a}$ \\
Corcolén-INIA & $29-06-07$ & $47.4 \mathrm{a}$ & $123.9 \mathrm{a}$ \\
Corcolén-INIA & $15-07-10$ & $53.5 \mathrm{a}$ & $86.9 \mathrm{a}$ \\
\hline & Mean & 47.9 & 109.6 \\
& $\mathrm{SD}$ & 5.5 & 21.6 \\
& $\mathrm{CV}, \%$ & 11.4 & 19.8 \\
\hline
\end{tabular}

SD: standard deviation; $\mathrm{CV}$ : coefficient of variation.

Values in columns followed by the same letter are not significantly different according to the $t$ test $(p>0.05)$.

initial leaves are substantially smaller in blade and leaf sheath area. In all cases (varieties and sowing dates) the maximum number of leaves was 8 , thus this is a conserved character in durum wheat.

Bassu et al. (2009) also estimated PHLN, obtaining mean values for different sowing dates of 120,136 , and $148{ }^{\circ} \mathrm{C}$ d leaf ${ }^{-1}$ for 'Simeto', 'Colosseo', and 'Creso', respectively. In this study there was a decrease in PHLN from 150 to $70{ }^{\circ} \mathrm{C} \mathrm{d}$ leaf ${ }^{-1}$ with sowing dates from October to March. These authors attributed the variation to day length to the sensitivity to photoperiod of the Italian varieties. However, it is important to note that in this case

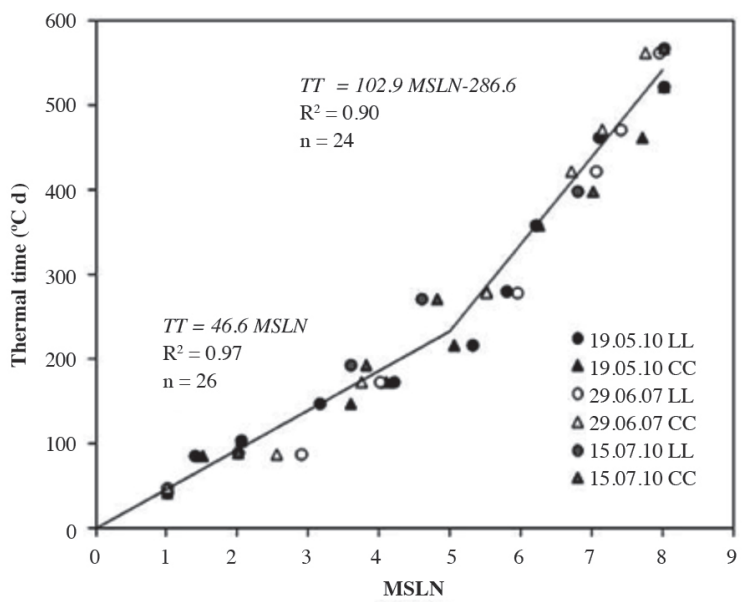

Figure 1. Relation between thermal time (TT; base temperature $=0$ ${ }^{\circ} \mathrm{C}$ ) and the main stem leaf number (MSLN) for 'Llareta-INIA' (LL) and 'Corcolén-INIA' (CC) in three sowing dates. 
thermal time was estimated by the absolute difference between mean air temperature and a base temperature $\left(0{ }^{\circ} \mathrm{C}\right)$ without considering that the development rate decreases below or above an optimum temperature (around $22{ }^{\circ} \mathrm{C}$ ), which tends to overestimate the thermal time of early sowing and thus the PHLN; this effect is particularly important in the pre-anthesis period in which the crop is exposed to lower temperatures compared to the period of grain filling.

The seasonal dynamics of LAI was represented by a dual sigmoid function. We identified two groups of data. The first, shown by the continuous line in Figure 2, is composed of sowing dates 19 May and 15 July 2010 and adjusted to the function LAI $=13.3(1 /(1+\mathrm{EXP}(-0.011 \mathrm{TT}-$ $351.5)))-\left(1 /(1+(\operatorname{EXP}(0.007 T T-815.5)))\left(\mathrm{R}^{2}=0.97 ; \mathrm{n}\right.\right.$ $=42$ ); the second group of sowing date 29 June 2007, which is represented by the dotted line, was adjusted to the function $\mathrm{LAI}=6.7(1 /(1+\mathrm{EXP}(-0.019 \mathrm{TT}-244.3)))-$ $\left(1 /(1+(\operatorname{EXP}(0.007 T T-872.6)))\left(\mathrm{R}^{2}=0.95 ; \mathrm{n}=22\right)\right.$. The varieties studied did not differ in LAI independent of sowing date, except for the maximum value reached, which in 2007 was approximately $37 \%$ less than for sowing dates of 2010. The differences observed in the maximum LAI $\left(\mathrm{LAI}_{\max }\right)$ reached in the $2 \mathrm{yr}$ were due to problems in irrigation during the 2007 season, which produced a decrease in leaf expansion and thus in leaf area. Giunta et al. (1995) obtained similar results, with a $32 \%$ reduction in $\mathrm{LAI}_{\max }$ in the durum wheat 'Tanit' exposed to water stress between the first node and ear emergence.

The maximum values of LAI found in this study were greater than $6 \mathrm{~m}^{2} \mathrm{~m}^{-2}$ in all treatments. These values are high compared to those reported by Royo et al. (2004), who evaluated 25 genotypes of durum wheat under irrigation in Lleida, Spain, with high sowing density (550 viable seeds $\mathrm{m}^{-2}$ ) and reported maximum LAI values of $3.5 \mathrm{~m}^{2} \mathrm{~m}^{-2}$ the first year and $5.5 \mathrm{~m}^{2} \mathrm{~m}^{-2}$ the second. They were also

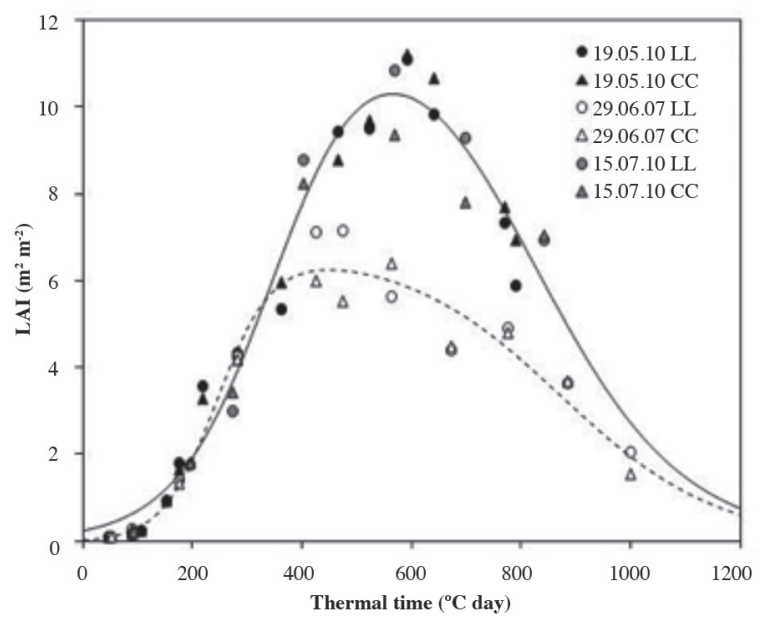

Figure 2. Leaf area index (LAI) of 'Llareta-INIA' (LL) and 'CorcolénINIA' $(\mathbf{C C})$ in three sowing dates as a function of thermal time (TT; base temperature $=0{ }^{\circ} \mathrm{C}$ ). The upper curve refers to 2010, and the lower curve to 2007. high compared to the $4.5 \mathrm{~m}^{2} \mathrm{~m}^{-2}$ considered as common in Mediterranean environments without water limitation in the vegetative growth stage of durum wheat (Lombardo and Tuttobene, 1987). Albrizio and Steduto (2005) also recorded maximum LAI values of $3 \mathrm{~m}^{2} \mathrm{~m}^{-2}$ before anthesis, in irrigated durum wheat in Velenzano, Italy.

\section{Light attenuation and radiation use efficiency}

Figure $3 \mathrm{a}$ shows the relation between interception of radiation and LAI for sowing dates and varieties. Given the lack of effect of variety and low effect of sowing date, we adjusted a unique exponential function (Equation [5]), resulting in a $k$ value of 0.46 , which gave a good adjustment for all data. The $k$ obtained was lower than those published for species such as quinoa $(k=0.52-0.58$; Ruiz and Bertero, 2008), 0.61 in beet (Hoffmann and Kluge, 2010), 0.63-0.80 in faba beans (Confalone et al., $2010)$, and greater than that of rye (0.43; Kemanian et al., 2004), while Evers et al. (2007) found values of 0.47 to 0.41 in low and high density populations of spring wheat (T. aestivum L., 'Minaret'), respectively (doses of 262 and $508 \mathrm{~kg}$ seeds ha-1).
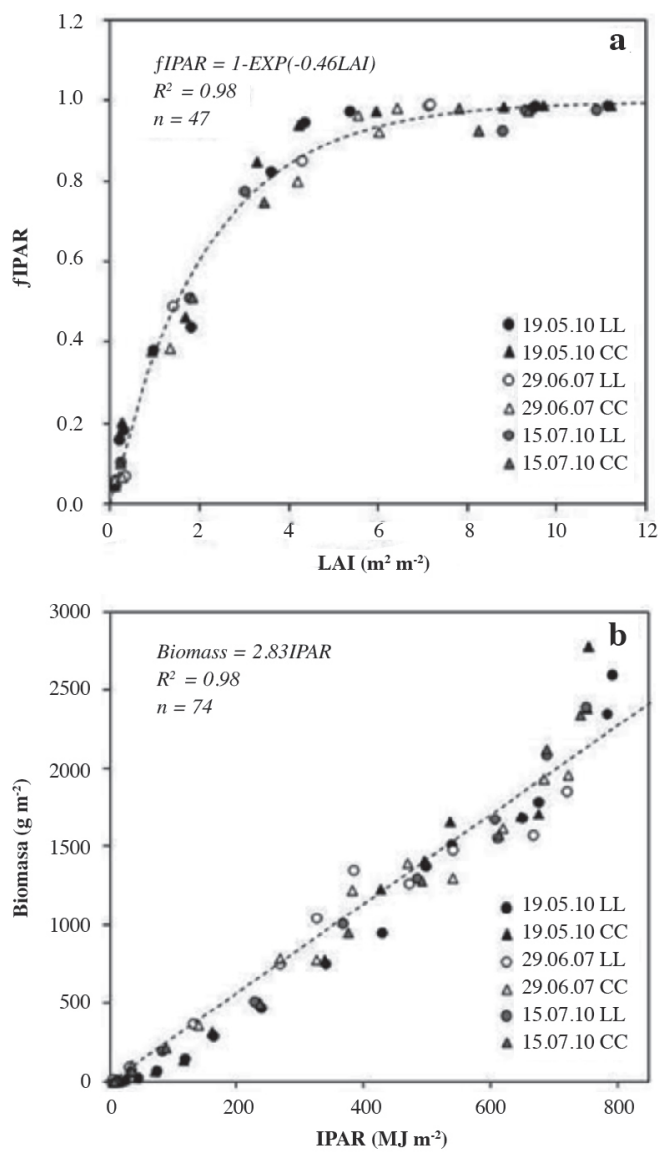

Figure 3. (a) Fraction of intercepted photosynthetically active radiation ( $f$ IPAR) as a function of leaf area index (LAI), and (b) cumulative biomass as a function of cumulative intercepted photosynthetically active radiation (IPAR) for 'Llareta-INIA' and 'Corcolén-INIA' in three sowing dates. 
All treatments intercepted more than $95 \%$ of incident radiation (Figure 3) around $350{ }^{\circ} \mathrm{C} \mathrm{d}$ and LAI around $6.5 \mathrm{~m}^{2} \mathrm{~m}^{-2}$, which occurred between the fifth and sixth leaf of the main steam. The total IPAR values were not statistically different among varieties and sowing dates, although there was a tendency to decrease in the intermediate sowing date (June) associated with lower values of $\mathrm{LAI}_{\max }$.

The $\mathrm{LAI}_{\mathrm{c}}$ values and $k$ in 'Llareta-INIA' did not vary significantly among sowing dates and were not different from those obtained for 'Corcolén-INIA'. The $\mathrm{LAI}_{\mathrm{c}}$ of the latter variety increased with later sowing date, which is explained by a decrease in $k$ from the early May to the late date of planting in June. The observed values of $\mathrm{LAI}_{\mathrm{c}}$ are quite large compared with those of Confalone et al. (2010) and Board and Harville (1992), who for faba bean and soya, obtained $\mathrm{LAI}_{\mathrm{c}}$ values in the range of 3.34.3 , respectively, largely explained by the characteristic horizontal leaves in legumes compared to the vertical leaves in cereals such as wheat, reflected in lower $k$ values.

One significant result of this study was the constancy of RUE during the crop growing season independent of the sowing date, which at this scale indicates constancy in the relation between assimilation and respiration as reported by Albrizio and Steduto (2003), which is one of the main assumption for the linearity of RUE (Dewar et al., 1998; Lafarge and Hammer, 2002), remembering that the reduced variation in RUE may be due to IPAR and seasonal biomass accumulation not being really independent (Demetriades-Shah et al., 1994). This result is consequent with reports for species such as wheat (O'Connell et al., 2004), rye (Kemanian et al., 2004), and durum wheat (Albrizio and Steduto, 2005). The values obtained are less than those reported by Albrizio and Steduto (2005) for the durum wheat 'Appullo' under conditions of irrigation, a RUE based on global intercepted radiation of $1.7 \mathrm{~g} \mathrm{MJ}^{-1}$, approximately $3.4 \mathrm{~g} \mathrm{MJ}^{-1}$ based on IPAR, very high for this species.

Independent of the differences observed in LAI and $k$, RUE fluctuated between 2.7 and $3.0 \mathrm{~g} \mathrm{MJ}^{-1}$ and was not significantly different among varieties and sowing dates (Table 6); thus we performed a single regression, which gave a general RUE value of $2.83 \mathrm{~g} \mathrm{MJ}^{-1}$ (Figure $3 b)$. The fact that RUE did not change significantly among sowing dates is interesting. In rye, Kemanian et al. (2004) found a significant decrease of RUE between early and late sowing, which they were able to normalize using the vapor pressure deficit, identified as the principal source of variation. However, Hoffmann and Kluge (2010) evaluated the effect of autumn and spring sowing on RUE and did not find a difference (2.4 and $2.2 \mathrm{~g} \mathrm{MJ}^{-1}$, respectively, based on photosynthetically absorbed radiation). It is expected that vapor pressure deficit would affect RUE in extreme conditions or where water availability is not optimum, given that it would influence daily assimilation due to stomata closing.
Table 6. Critical leaf area index (LAI $)$ or LAI that intercepts $95 \%$ of the incoming solar radiation, photosynthetically active radiation (PAR), extinction coefficient (k), cumulative intercepted (PAR) (IPAR) between emergence and physiological maturity and PAR use efficiency (RUE) obtained from IPAR for 'Llareta-INIA' and 'Corcolén-INIA' in three sowing dates.

\begin{tabular}{llllll}
\hline Cultivar & Sowing date & LAI $_{\mathrm{c}}$ & $\mathrm{k}$ & IPAR & RUE $^{1}$ \\
\hline & & & & $\mathrm{MJ} \mathrm{m}^{-2}$ & $\mathrm{~g} \mathrm{MJ}^{-1}$ \\
Llareta-INIA & $19-05-10$ & $6.2 \mathrm{ab}$ & $0.49 \mathrm{ab}$ & $789.2 \mathrm{a}$ & $2.8 \mathrm{a}$ \\
Llareta-INIA & $29-06-07$ & $6.1 \mathrm{ab}$ & $0.50 \mathrm{ab}$ & $722.0 \mathrm{a}$ & $2.7 \mathrm{a}$ \\
Llareta-INIA & $15-07-10$ & $6.6 \mathrm{ab}$ & $0.47 \mathrm{ab}$ & $773.5 \mathrm{a}$ & $3.0 \mathrm{a}$ \\
Corcolén-INIA & $19-05-10$ & $5.8 \mathrm{~b}$ & $0.52 \mathrm{a}$ & $752.8 \mathrm{a}$ & $3.0 \mathrm{a}$ \\
Corcolén-INIA & $29-06-07$ & $6.7 \mathrm{ab}$ & $0.45 \mathrm{ab}$ & $725.8 \mathrm{a}$ & $2.7 \mathrm{a}$ \\
Corcolén-INIA & $15-07-10$ & $7.5 \mathrm{a}$ & $0.41 \mathrm{~b}$ & $770.1 \mathrm{a}$ & $2.9 \mathrm{a}$ \\
\hline & Mean & 6.5 & 0.47 & 755.6 & 2.9 \\
& $\mathrm{SD}$ & 0.6 & 0.04 & 27.1 & 0.1 \\
& $\mathrm{CV}, \%$ & 9.2 & 8.3 & 3.6 & 4.8 \\
\hline
\end{tabular}

SD: standard deviation; CV: coefficient of variation.

Values in columns followed by the same letter are not significantly different according to Duncan's test ( $\mathrm{p}>0.05)$.

${ }^{1}$ Values in columns of RUE followed by the same letter are not significantly different according to the $t$ test $(p>0.05)$.

\section{Validation of the genetic coefficients}

In order to evaluate the performance of the genetic coefficients associated with development obtained in this study, simulations were performed for time of anthesis and physiological maturity with the measured thermal times. The simulated data for days to anthesis and physiological maturity obtained with Equation [1] (daily calculation) were contrasted with those obtained by Olivieri (2009) in a trial of sowing date and distance between rows for 'Llareta-INIA' in the locality of Cauquenes, and Yungay, during the 2008-2009 season (Table 2). The phenological model (Equations [1], [2] y [3]) estimated well days to anthesis and physiological maturity in Cauquenes, especially for early sowing date (Figure 4).

However, the model tended to overestimate slightly days to anthesis for Yungay and length of the complete cycle for both localities; however, in all cases estimates were quite close and the tendency for increase in the

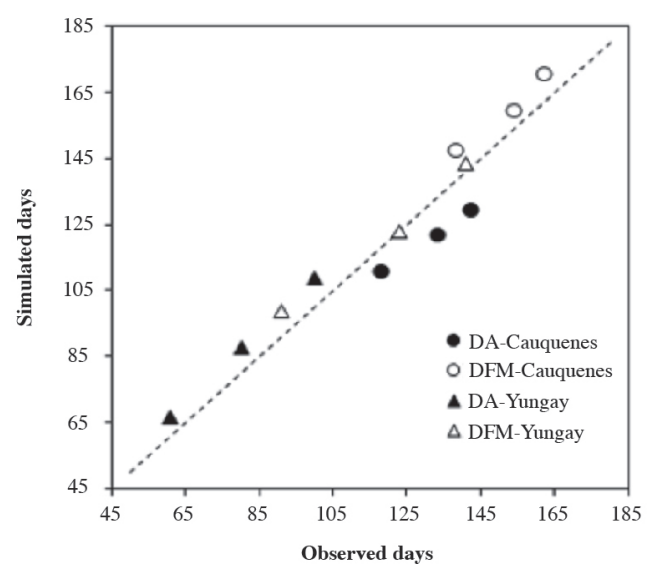

DA: Days to anthesis; DFM: Days to physiological maturity

Figure 4. Simulated and observed data for days to anthesis and physiological maturity for 'Llareta-INIA' in the localities of Cauquenes and Yungay during the 2008-2009 season. 
number of days was linear and parallel to an adjustment of 1:1. RMSE for days to anthesis at Cauquenes was 10.2 and for days to physiological maturity was $8.5 \mathrm{~d}$ respectively. RMSE for days to anthesis at Yungay was 7.8 and for days to physiological maturity was $5 \mathrm{~d}$ respectively. The RMSE in Equation [6] represents a measure of the overall, or mean, deviation between observed and simulated values, that is, a synthetic indicator of the absolute model uncertainty. In fact, it takes the same units of the variable being simulated, and therefore the closer the value is to zero, the better the model simulation performance.

We used a simple model for generation of dry material based on radiation. The accuracy of the prediction performance in the location of Santiago was higher than in Chillán (Figure 5), with a RMSE of 595.8 (\%) and 2447.9 $\mathrm{kg} \mathrm{ha}^{-1}(\%)$ respectively, with a significant overestimation of performance under Chillán conditions. This appears to be explained by the decrease in temperature that lengthens the duration of the growing season, which also results in higher amount of radiation being intercepted and higher yield production. Fischer (1985) mentioned that higher values of photothermal quotient during the critical period of wheat cultivation ( $31 \mathrm{~d}$ before anthesis to $10 \mathrm{~d}$ after anthesis) maximize yield of varieties. As the model simulates the growth considering temperature and radiation, the field yield is overestimated, due to some stress.

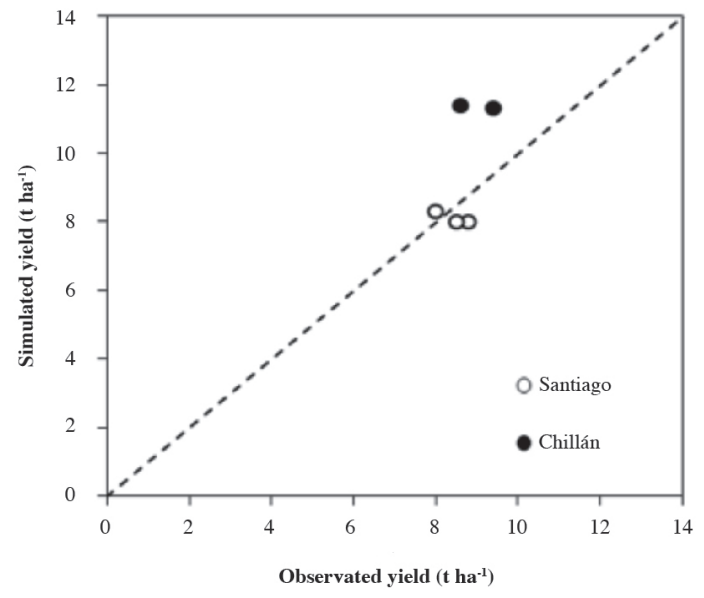

Figure 5. Simulated and observed data for grain yield for 'LlaretaINIA' in the localities of Santiago and Chillán during the 2008-2009 season.

\section{CONCLUSIONS}

The genetic coefficients evaluated in this study were stable, being the same for various sowing dates and varieties of durum wheat. The observed differences in the maximum LAI produced by water stress in the intermediate sowing date did not affect the calculated genetic coefficients, because independent of stress high values of LAI were achieved and thus the interception of maximum radiation.

With respect to phenological thermal time, the multiplicative model which considers the accumulation of thermal time and a temperature correction factor (beta function) was appropriate to quantify development, given that it strongly decreased the observed variability in terms of days to anthesis and physiological maturity in the different treatments.

The validation of the phenology was satisfactory and an overestimation of performance under locations of high potential of yield derivate from simplicity of the model, no from efficiency of genetic coefficients.

\section{ACKNOWLEDGEMENTS}

This work was financed by projects FIA-ES-L-20051-A-003 and PDT-2007-190.

\section{LITERATURE CITED}

Albrizio, R., and P. Steduto. 2003. Photosynthesis, respiration and conservative carbon use efficiency of four field grown crops. Agricultural and Forest Meteorology 116:19-36.

Albrizio, R., and P. Steduto. 2005. Resource use efficiency of fieldgrown sunflower, sorghum, wheat and chickpea I. Radiation use efficiency. Agricultural and Forest Meteorology 130:254-268.

Bassu, S., S. Asseng, R. Motzo, and F. Giunta. 2009. Optimising sowing date of durum wheat in a variable Mediterranean environment. Field Crops Research 111:109-118.

Board, J.E., and B.G. Harville. 1992. Explanations for greater light interception in narrow- vs. wide-row soybean. Crop Science 32:198-202.

CIREN. 1996. Descripción de suelos materiales y símbolos. Estudio Agrológico Región Metropolitana. Publicación CIREN N ${ }^{\circ} 115$. Centro de Información de Recursos Naturales (CIREN), Santiago, Chile.

Confalone, A., J. Lizaso, B. Ruiz-Nogueira, F. Lopez, and F. Sau. 2010. Growth, PAR use efficiency, and yield components of fieldgrown Vicia faba L. under different temperature and photoperiod regimes. Field Crops Research 115:140-148.

Cumsille, F. 1995. Métodos estadísticos. 37-45 p. Publicaciones Universidad de Chile, Facultad de Medicina, Santiago, Chile.

De Candolle, A. 1855. Géographie botanique raisonnée. Masson, Paris, France.

Del Pozo, L. 1988. El rol de la temperatura y radiación solar en el crecimiento y la producción del trigo primaveral, con diferentes épocas de siembra. AgriculturaTécnica (Chile) 48:241-243.

Demetriades-Shah, T.H., M. Fuchs, E.T. Kanemasu, and I. Flitcroft. 1994. Further discussions on the relationship between cumulated intercepted solar radiation and crop growth. Agricultural and Forest Meteorology 68:231-242.

Dewar, R.C., B.E. Medlyn, and R.E. McMurtie. 1998. A mechanistic analysis of light and carbon use efficiencies. Plant and Cell Environment 21:573-588.

Diffenbaugh, N., J. Pal, F. Giorgio, and X. Gao. 2007. Heat stress intensification in the Mediterranean climate change hotspot. Geophysical Research Letters 34(11):L11706.

Evers, B., J. Vos, C. Fournier, B. Andrieu, M. Chelle, and P. Struik. 2007. An architectural model of spring wheat: Evaluation of the effects of population density and shading on model parameterization and performance. Ecological Modelling 200:208-320.

Fischer, R.A. 1985. Number of kernels in wheat crops and the influence of solar radiation and temperature. Journal of Agricultural Science Cambridge 105:447-461.

Giunta, F., R. Motzo, and M. Deidda. 1995. Effects of drought on leaf area development, biomass production and nitrogen uptake of durum wheat grown in a Mediterranean environment. Australian Journal of Agricultural Research 46:99-111. 
Gregory, P.J., D. Tennant, and R.K. Belford. 1992. Root and shoot growth, and water and light use efficiency of barley and wheat crops grown on a shallow duplex soil in a Mediterranean-type environment. Australian Journal of Agricultural Research 43:555573.

Hoffmann, C., and S. Kluge. 2010. Light absorption and radiation use efficiency of autumn and spring sown sugar beets. Field Crops Research 119:238-244.

INIA. 1989. Mapa agroclimático de Chile. 221 p. In Novoa, R., y S. Villaseca (eds.) Instituto de Investigaciones Agropecuarias INIA, Santiago, Chile.

Jamieson,P.D., M.A. Semenov,I.R. Brooking, and G.S.Francis.1998. Sirius: A mechanistic model of wheat response to environmental variation. European Journal of Agronomy 8:161-179.

Kaur, M., K. Singh, H. Singh, P. Singh, and S. Tabasum. 2007. Evaluation of model CERES-Wheat (Ver. 4.0) under temperate condition of Kashmir valley. World Journal of Agricultural Sciences 3:825-832.

Kemanian, A., C. Stockle, and D. Huggins. 2004. Variability of barley radiation-use efficiency. Crop Science 44:1662-1672.

Lafarge, T.A., and G.L. Hammer. 2002. Predicting plant leaf area production: shoot assimilate accumulation and partitioning, and leaf area ratio, are stable for a wide range of sorghum population densities. Field Crops Research 77:137-151.

Lombardo, G.M., e R. Tuttobene. 1987. Relazioni tra Somme termiche, fenofasi e accrescimento in frumento (Triticum spp.) Italian Journal of Agronomy 21:337-344.

Marquardt, D.W. 1963. An algorithm for least-squares estimation of nonlinear parameters. Journal of the Society for Industrial and Applied Mathematics 11:431-441.

McCown, R.L., G.L. Hammer, J.N.G. Hargreaves, D.P. Holzworth, and D.M. Freebairn. 1996. APSIM: A novel software system for model development, model testing, and simulation in agricultural systems research. Agricultural Systems 50:255-271.

Monsi, M., und T. Saeki. 1953. Über den Lichtfaktor in den Pflanzengesellschaften und seine Bedeutungfür die Stoffproduktion. Japanese Journal of Botany 14:22-52.

O'Connell, O., G. Leary, D. Whitfield, and D. Connor. 2004. Interception of photosynthetically active radiation and radiation use efficiency of wheat, field pea and mustard in a semi-arid environment. Field Crops Research 85:111-124.

Olivieri, V. 2009. Efecto de la distancia entre hilera en la eficiencia en el uso del agua en trigo candeal en secano Mediterráneo. 57 p. Tesis Magister en Ciencias Agropecuarias. Universidad de Chile, Santiago, Chile.

Pala, M., C. Stockle, and H. Harris. 1996. Simulation of durum wheat (Triticum turgidum ssp. durum) growth under different water and nitrogen regimes in a Mediterranean environment using CropSyst. Agricultural Systems 51:147-163.
Reynolds, M.P., M. Van Ginkel, and J.M. Ribaut. 2000. Avenues for genetic modification of radiation use efficiency in wheat. Journal of Experimental Botany 51:459-473.

Rinaldi, M. 2004. Water availability at sowing and nitrogen management of durum wheat: a seasonal analysis with the CERES-Wheat model. Field Crops Research 89:27-37.

Rosenberg, N., B. Blad, and S. Verma. 1983. Microclimate: The biological environment. $2^{\text {nd }}$ ed. John Wiley and Sons, New York, USA.

Royo, C., N. Aparicio, R. Blanco, and D. Villegas. 2004. Leaf and green area development of durum wheat genotypes grown under Mediterranean conditions. European Journal of Agronomy 20:419-430.

Ruiz, R., and H. Bertero. 2008. Light interception and radiation use efficiency in temperate quinoa (Chenopodium quinoa Willd.) cultivars. European Journal of Agronomy 29:144-152.

Sandrini, L., L. Hostin, P. Lana, y F. Pellizzari. 2007. Un nuevo método de análisis digital para la determinación de los niveles de consumo foliar. Investigaciones Marinas, Valparaíso 35:111-116.

Silva, P., J. Kolopp, y E. Acevedo. 2007. Trigo candeal: ¿dónde cultivar para tener una mejor calidad? p. 89-102. In Acevedo, E., y P. Silva (eds.) Trigo candeal: Calidad, mercado y zonas de cultivo. Serie Ciencias Agronómicas $N^{\circ} 12.182$ p. Universidad de Chile, Santiago, Chile.

Sinclair, T.R., and R.C. Muchow. 1999. Radiation use efficiency. Advances in Agronomy 65:215-265.

Skylas, D., S. Cordwell, P. Hains, M. Larsen, D. Basseal, B. Walsh, et al. 2002. Heat shock of wheat during grain filling: proteins associated with heat-tolerance. Journal of Cereal Science 35:175188.

Stapper, M., and J.M. Lilley. 2001. Evaluation of simtag and nwheat in Simulating Wheat Phenology in Southeastern Australia. Proceedings of the $10^{\text {th }}$ Australian Agronomy Conference, Hobart. Available at http://www.regional.org.au/au/asa/2001/1/d/stapper. htm (accessed August 2012).

Steel, R.G.D., y J.H. Torrie. 1985. Bioestadística: Principios y procedimientos. 622 p. McGraw-Hill, México.

Takahashi, T., and K. Nakaseko. 1990. Seasonal change of photosynthetically active radiation intercepted by a spring wheat canopy and its relation to dry matter production. Japan Journal of Crop Sciences 59:778-784.

Turner, N.C. 2004. Agronomic options for improving rainfalluse efficiency of crops in dryland farming systems. Journal of Experimental Botany 55:2413-2425.

Xue, Q., A. Weiss, and S. Baenziger. 2004. Predicting leaf appearance in field-grown winter wheat: evaluating linear and non-linear models. Ecological Modelling 175:261-270.

Zadoks, J.C., T.T. Chang, and C.F. Konzak. 1974. A decimal code for the growth stage of cereals. Weed Research 14:415-421. 